\title{
Zimbabwe's Emigrants: Growth and Change in Australia
}

\author{
Barbara Edgar \\ School of Demography, The Australian National University \\ barbara.edgar@anu.edu.au \\ David Lucas \\ School of Demography, The Australian National University \\ david.lucas@anu.edu.au
}

\begin{abstract}
Prior to 2006 the Zimbabwe-born in Australia were largely ignored or subsumed within broader geographical "Africa” categories. However between 2001 and 2006 their numbers almost doubled to become the second most numerous birthplace group from sub-Saharan Africa. This prompted Lucas, Jamali and Edgar (2011) to analyse their basic characteristics, one finding being that they were increasingly of nonEuropean ancestry. This article builds upon this work by analysing 2011 Australian census data with a particular focus on European and African components of the Zimbabwe-born. It examines the age/sex structures, occupations, industries, and Australian citizenship take-up rates of each subgroup, identified by their ancestries and languages. Both components are strongly represented in managerial/professional occupations. Unlike the situation in the United Kingdom, mentioned below, there is no strong evidence of deskilling. Although the ethnic composition has changed, the high socioeconomic status of Zimbabwean immigrants is indicated by the predominance of skilled migrants among settler arrivals since 1991. This is contrasted with immigrants from refugee source countries in Africa, who have often experienced interrupted schooling. Another finding is that the majority of both English speakers and African language speakers have taken up Australian citizenship, suggesting that return migration is unlikely to be significant in the immediate future. The substantial flows from Zimbabwe to Australia since 2000 are shown to reflect government policies and the state of the economy in both countries.
\end{abstract}




\section{Introduction $^{1}$}

Australian censuses have recorded a doubling in the number of persons born in sub-Saharan Africa in the decade after 2001, to total 295,375 in 2011. The majority of these were either South Africa-born or Zimbabweborn. They were also predominantly skilled migrants, for example between 2001 to 2008 around $85 \%$ of settlers from both these countries were skilled migrants (Lucas \& Edgar, 2013). This article focusses on the stages of Zimbabwean immigration to Australia and how this skilled migration stream changed from being predominantly white/European to being predominantly black African. Since, historically, this migration stream comprised mainly white middle-class Zimbabweans (Forrest, Johnston \& Poulsen, 2013), the article begins with a demographic history of factors influencing Europeans to emigrate from Zimbabwe. This is followed by a discussion of relevant Australian data sources and an examination of reasons for the growth of the Zimbabwe-born population in Australia. Next the Zimbabwe-born are briefly compared and contrasted with other key streams from Africa. The final sections analyse and compare the characteristics of the African and European components of Zimbabwe-born in 2011, with a particular focus on their age/sex structures, occupations, industries, and Australian citizenship take-up rates.

The country of Zimbabwe did not come into existence until 1980 so the term 'Rhodesia' is used in this article for the period between 1965, when the Unilateral Declaration of Independence was declared, and 1980 when political independence was achieved. Prior to 1965 the country was known as Southern Rhodesia. The terms 'European' (preferred in official statistics) and 'white' (preferred by the media) are used interchangeably. The majority population of Zimbabwe are ethnic Africans (Zimbabwe Population Census Office, 2014).

Forrest et al. (2013) have observed that in the recent transmigration literature "much less emphasis has been placed on immigrants from cultural backgrounds similar to those of their host country". Until recently, this was true for the Zimbabwe-born in Australia who were largely ignored or subsumed within a "southern African" category (see, for example Kennedy, 1988). An exception is the 1996 snapshot by Hugo (1999) which found many similarities between the Zimbabwe- and South Africa-born in Australia.

\footnotetext{
${ }^{1}$ The authors acknowledge and thank the anonymous reviewers and the editors for their constructive comments.
} 
In the 21st century, as flows from Zimbabwe to Australia increased and additional data sources became available, these immigrants started to receive more attention (Hugo, 2009; Lucas, Jamali \& Edgar, 2011; Forrest et al., 2013). At the 2001 census there were only 11,734 Zimbabwe-born in Australia. However, by the 2006 census the population had increased $72 \%$ to 20,155, moving into second place after South Africa among sub-Saharan African source countries. This prompted Lucas, Jamali and Edgar (2011) to analyse the basic characteristics of the Zimbabwe-born, confirming Hugo's (1999) finding that they were a highly-educated and skilled group. What Hugo (1999) did not specify is that they were also almost entirely European. Zimbabwean census data record the near disappearance of the European population since 1970. The quantum of and reasons for this decline are discussed in the following section, entitled Historical push factors affecting Europeans in Zimbabwe.

This article examines how Zimbabwe has become a significant source of Australian immigrants, especially in the 21st century. The analysis extends the previous Lucas et al. (2011) study of the Zimbabwe-born which was based on the 2006 census, and the more recent profile which described their basic spatial and demographic characteristics in 2011 but did not analyse European/African components of Zimbabwe-born (Lucas \& Edgar, 2015). A separate study by Forrest et al. (2013) used 2006 census data to analyse southern African residential patterns in Perth; it also used longitudinal survey data between 1995 and 2006 to analyse experiences of resettlement in the first 18 months but the analysis was hampered by small numbers of Zimbabwe-born (83 respondents) and did not distinguish between males and females.

The historical analysis in this article shows how flows from Zimbabwe to Australia have been related to specific government policies and economic factors in both countries. Although the initial wave of European Zimbabweans moving to Australia which began at the turn of the 21st century has been virtually exhausted, it is being followed by a smaller flow of African Zimbabweans which has been little analysed. As discussed later in this article, the key change in ethnic composition occurred between 2006 and 2011, when for the first time Zimbabwe-born arrivals who spoke an Indigenous African language (predominantly Shona), outnumbered English-speakers. Speaking an Indigenous language at home is indicative of an African, as opposed to a European, heritage. The 2011 Australian census has provided an opportunity to compare the occupational and other characteristics of each group, which this article will now proceed to do. 
Of particular interest is whether the recent wave of African settlers from Zimbabwe, like the earlier European arrivals, are on a pathway to successful settlement in keeping with their skills and education. New immigrants are particularly susceptible to periods of unemployment (Richardson, Robertson \& Ilsley, 2001) and the on-going reduction in skilled jobs in mining and other sectors might well mean lower wages and reduced prospects for promotion for new arrivals entering the labour market (Department of Employment, 2015; Tulip, 2014). An issue for the African component in particular is the potential for employer discrimination based on visual difference. A national study of attitudes to, and experiences of, racism based on random phone interviews with 12,500 people found that forms of discrimination exist in Australia at both institutional and "everyday" levels (Western Sydney University, n.d.). However, other studies have found little evidence that employer discrimination is affecting migrants (Forrest \& Johnston, 1999; Forrest, Poulsen \& Johnston, 2006; Wooden, 1994).

\section{Historical push factors affecting Europeans in Zimbabwe}

The European population of Zimbabwe/Rhodesia arrived and largely disappeared within less than a hundred years, as shown graphically in Figure 1. Most whites in Zimbabwe have been immigrants (Mlambo, 2010) and "always especially subject to stresses that could induce emigration" (Brownell, 2008, p. 600). Unlike Mozambique and Angola, which both experienced a massive exodus of their European populations at the end of the 1970s (Hammer, 2010), the exodus from Zimbabwe was spread over several decades.

In 1911 the European population in Rhodesia numbered around 24,000. Between 1941 and 1957 the total population rose from approximately 1.5 million to over 2.5 million but the number of Europeans almost tripled, from around 67,000 to 193,000 due "to the unprecedented rate of immigration since the war” (Gordon-Brown, 1959, p. 261). In 1969 the European population of Rhodesia reached a peak of 230,000.

A fear of being racially swamped was always a source of anxiety for the white minority in Rhodesia and when the 1969 census revealed a widening gap between white European and African demographic trends, new uncertainty arose about the viability of white Rhodesia in post-colonial Africa (Brownell, 2008). Indeed 1969 was a turning point after which the number of Europeans in the country declined rapidly as the security situation deteriorated into civil war during the war of liberation. For many, the decision to leave Rhodesia would not have been difficult, as "settlers 
had a long history of drifting in and out of Rhodesia and other British territories in eastern and southern Africa without ever acquiring any significant loyalty to Rhodesia in particular ... returning home was always a viable option” (Brownell, 2008, p. 592).

The Zimbabwean national liberation struggle culminated in the creation of the Republic of Zimbabwe in 1980 with Robert Mugabe as Prime Minister (Kay, 1988). Upon coming to power Mugabe urged national reconciliation and unity. Nevertheless, he increasingly took to targeting whites for public criticism, accusing them of "not accepting the black hand of friendship" (Fisher, 2010, p. 44). In this climate substantial numbers of Europeans continued to leave Zimbabwe after independence. From 1980 to 1983 documented emigration totalled nearly 75,000 with the majority (58\%) moving to South Africa, 20\% to Other Africa, $11 \%$ to the United Kingdom and 4\% to Australia (Zinyama, 1990; Tevara \& Zinyama, 2002).

Growing restrictions by the Zimbabwean Government on citizenship and residence rights in the decades following independence were additional factors which encouraged Europeans to leave. Zimbabwean citizens were prohibited from holding dual passports as far back as 1984. One Australian citizen whose Zimbabwean citizenship was revoked is the CEO of the aid agency CARE Australia, Julia Newton-Howes (personal communication). Born in India, Newton-Howes spent her early life in Rhodesia before attending London University and eventually migrating to Australia (National Museum Australia, 2014). In 1996 children born in Zimbabwe to permanent residents lost their automatic right citizenship, and foreign-born wives lost their right to live in Zimbabwe (Fisher, 2010).

By the 1990s, the remaining European community was experiencing a growing sense of estrangement from the wider community, and some reconsidered whether they should stay on, as their friends and relatives continued to leave Zimbabwe (Fisher, 2010). From the late 1990s there were increasing, often irresistible, economic reasons to leave. In 1997 Mugabe decided to mollify the Zimbabwe National War Veterans Association by seizing white farms without compensation, leading to a rapid economic collapse where "possibly as many as a million peasants were teetering on the brink of famine" (Nugent, 2004, p. 408).

Subsequently, the country's downward economic spiral in the early 21st century was a strong factor encouraging emigration (Bratton \& Masunungure, 2006), and was reinforced by fears for personal safety due to the coincident civic unrest. The experiences of the family of David Pocock, star Australian player of the 2015 World Rugby Cup, exemplify the concerns felt by many Zimbabwean farmers at the time. Pocock has said 


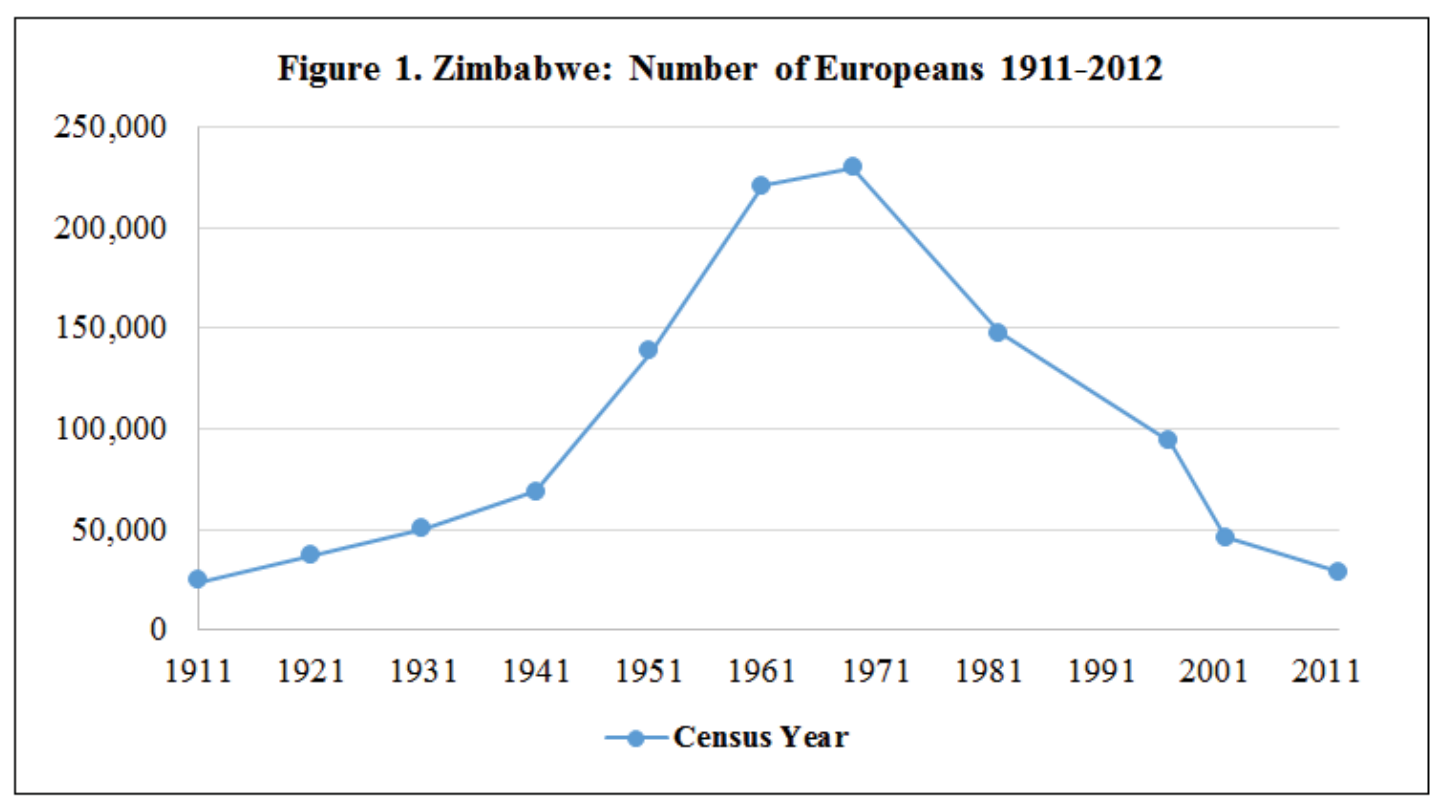

Sources: Mlambo 2010. Zimbabwe Central Statistical Office 1985; 1998; 2004. Zimbabwe

Population Census Office 2014.

that a murderous attack on their neighbours gave his family their final warning that it was time to flee the strife-torn country (Geenty, 2009). The Zimbabwe Population Census Office (2014) reports that the declining European population fell a further 37\% in the period 2002-12, and by 2012 had dwindled to $28,732(0.2 \%)$ out of a total population of 13 million.

\section{Data and methods}

Data tables from the 2011 Australian census were produced and extracted by the authors using the Australian Bureau of Statistics' TableBuilder software. Australian citizenship data were extracted from the 2011 Australian Census and Migrants Integrated Dataset using TableBuilder. Australia holds a census every five years which identifies Zimbabwe-born persons living in Australia. The census also provides language and ancestry data which have been used in this study to distinguish between the European and African components of the Zimbabwe-born. These data provide an approximate representation of each subgroup.

Census respondents could provide up to two ancestries, and three quarters of Zimbabwe-born gave a single ancestry while one quarter gave two ancestries. In this article, ancestry data are the weighted sum of both responses. The "Zimbabwean" ancestry category does include some of European origin who nominated "Rhodesian" ancestry; in the census dataset "Rhodesian" was re-coded to "Zimbabwean" and the original response data are not available. The "African, so described" category may 
include persons of European descent who identify as African. Additionally, as movements between the countries of southern Africa were commonplace, Zimbabweans of European descent may have parents who were born outside Europe.

Census data cannot identify immigrants to Australia who spent much of their lives in Zimbabwe but were not born there. For example, the Bundu Times, published in Western Australia by the Rhodesian Association, indicated that several members were born in South Africa or Britain before emigrating to Rhodesia and then to Australia.

The authors have partially addressed this gap by the manual creation and analysis of a database derived from basic case histories of former students of Peterhouse, who are known as "Petreans". Peterhouse is a prestigious group of independent Rhodesian/Zimbabwean schools. Founded in the late 1950s it caters for students from pre-school to 6th Form (equivalent to Year 12 in Australia). The websites of the Peterhouse Petrean Society and its predecessor, the Petrean Bush Telegraph, publish news of former pupils. The Petrean database, used in analysis which follows, has been drawn from these websites. An important advantage over the census is that many informants have provided a brief migration history, and often their tertiary education and employment after leaving school. The data are highly selective since Peterhouse students are generally from well-off families and many former students do not contribute to the website.

To supplement the above data sources, the authors extracted settler arrival flow data for the period 1991-2013 from the Settlement Reporting Facility of the Department of Social Services. Settler arrivals data are used in the analysis to distinguish different types of Africa-born immigrants based on their visa: skilled migrants; family reunion migrants; and humanitarian entrants who comprise refugees and others fleeing persecution.

\section{Growth of the Zimbabwe-born population in Australia}

This section identifies the factors affecting flows from Zimbabwe to Australia and analyses the outcomes in terms of Australia's population. Historically, Australia had few settlers from Zimbabwe. South Africa has long been the favoured destination for Zimbabweans and in the 1980s and early 1990s the United Kingdom became a more important destination. The Zimbabwe-born population in England and Wales increased by $136 \%$ between 1991 and 2001 (Office for National Statistics, 2013). This changed at the beginning of the 21st century when the British Government imposed visa restrictions on Zimbabweans, contributing to a fall in the number 
entering the United Kingdom, from 56,600 in 2002 to 39,250 in 2007 (Crush \& Tevera, 2010).

Meanwhile, from the late 1990s several factors encouraged more Zimbabwean emigrants to choose Australia as a destination. During the 1990s white Zimbabweans had learned about Australia from TV shows such as Neighbours and also from migration seminars "specifically aimed at attracting people to Australia” (Fisher, 2010, p. 7). Australia was seen as a place of opportunity. It shared a common history with Zimbabwe as a former colony of England. Sport was important to both communities (Fisher 2010) and former Australian Senator Andrew Murray, who grew up in Rhodesia, said that one reason people from his part of the world chose Australia as a destination was their love of sport (ABC, 2003). This was echoed by community development practitioner Oliver Maboreke, who became an Australian citizen in 2009 and chose Australia because of its sports and wildlife (Settlement Services International, 2014).

Denise Fisher was Australia's High Commissioner in Harare from 1998 to 2001. She records that the Australian Government was pro-active in facilitating the emigration of large numbers of European Zimbabweans, sending extra officials to Harare to assist the hundreds of prospective settlers seeking visas to Australia (Fisher, 2007).

The above factors facilitated substantial movements from Zimbabwe to Australia. Excluding the countries in Africa, Australia was the second most popular destination after the United Kingdom for Zimbabwean emigrants in the period 1998-2005. In total, some 10,600 Zimbabwean residents moved to Australia in that period, compared with 45,385 who moved to the United Kingdom, 3225 to Canada, and 2356 to New Zealand; 3560 Zimbabweborn also moved to the USA (United Nations Population Division, 2015).

From around 2005, a mining boom strengthened the Australian economy and generated employment opportunities which attracted immigrants. The outcome was a huge surge in net migration to Australia from across the globe from 2006 onwards (McDonald, 2015). In particular, the Zimbabwe-born population in Australia continued to grow rapidly after 2006.

Figure 2 shows the growth in Zimbabwe-born numbers since 1981, with a steeper trend line from the turn of the 21st century. The population grew 72\% between 2001 and 2006, and a further 50\% from 2006 to the 2011 census when 30,251 Zimbabwe-born were enumerated (Lucas \& Edgar, 2013). In total, the population grew by 158\% between 2001 and 2011, comparable to the 151\% increase in England and Wales (Office for National Statistics, 2013). 


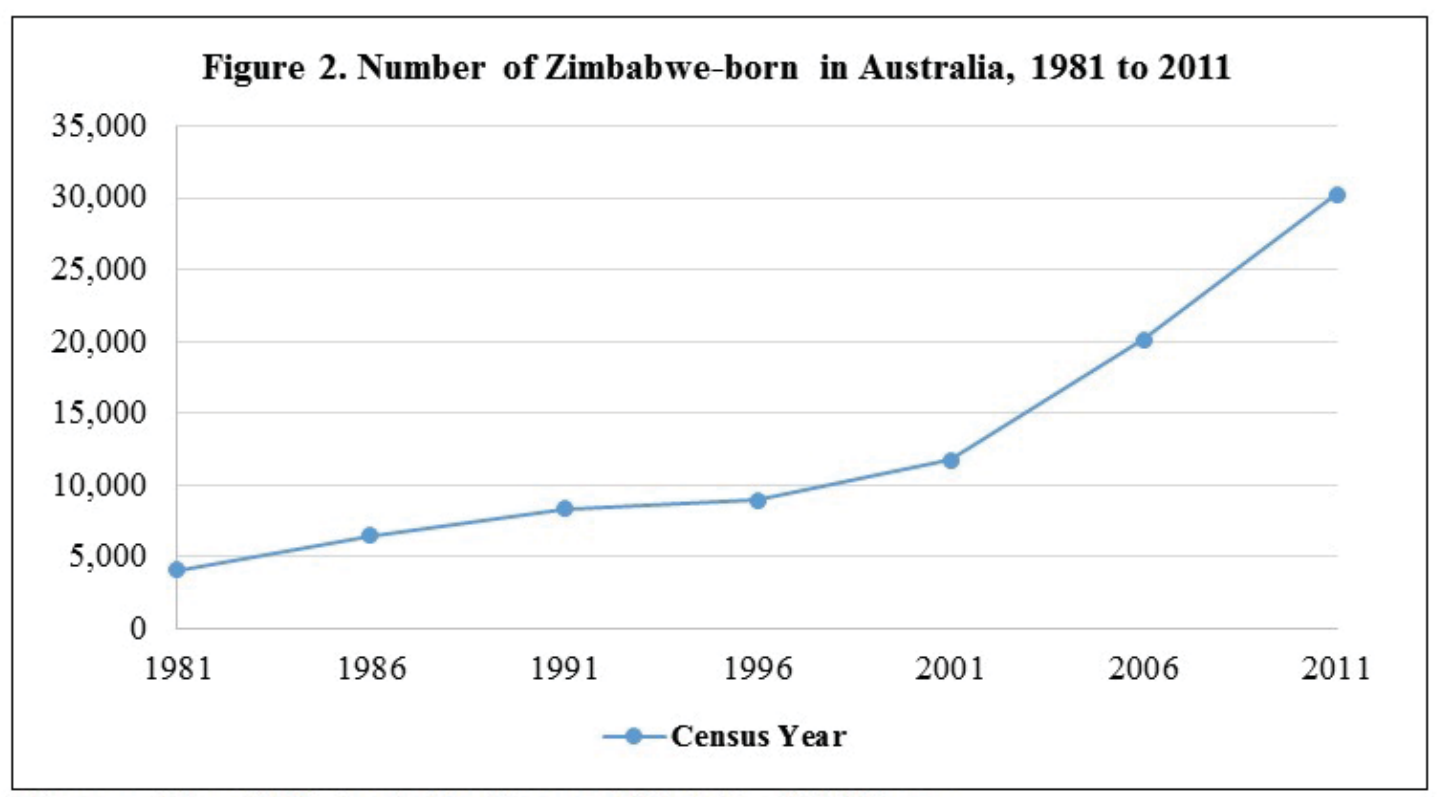

Sources: Hugo 2009. Australian Bureau of Statistics, 2011 Census.

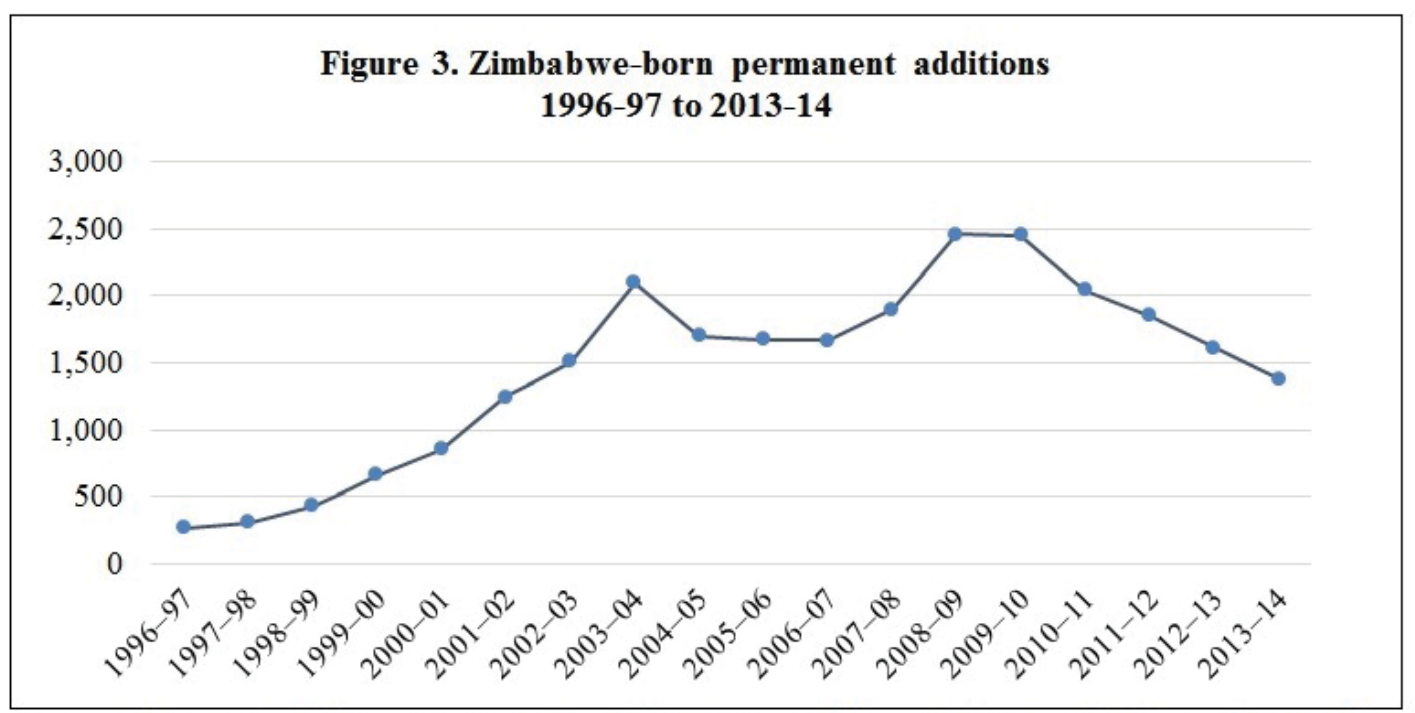

Source: Department of Immigration \& Border Protection. Historical Migration Statistics, March 2015. Note: Permanent additions comprise persons who arrive from overseas entitled to stay permanently in Australia; and persons in Australia on a temporary basis who are granted permanent residence status.

Figure 3 shows the number of Zimbabwe-born permanent additions to the Australian population each financial year from 1996-97 to 2013-14. The numbers from 2002-03 to 2012-13 exceeded 1500 annually, with the largest gain occurring around 2009. These data, unlike the census, do not include the many Zimbabweans living and working in Australia who are not permanent residents. 
At 30 June 2011, there were 1,432 holders of temporary skilled worker visas (subclass 457) who were born in Zimbabwe (DIAC, 2011). In 2012, Public Services International released a study of 478 female migrants from 57 countries who had come to work in Australian healthcare, primarily as nurses (Pillinger, 2012). Zimbabwe was one of the top five countries of origin among survey respondents. About half of the sample had travelled on subclass 457 visas.

The subclass 457 visa often provides a pathway to permanent residence. Since the mid-1990s, Australia's skilled permanent and skilled temporary visa programs have gradually been merging into a single system in which permanent migration is commonly preceded by a period of temporary migration; most new permanent skilled immigrants make an application in Australia while holding a temporary visa such as the 457 (McDonald, 2015).

Analysis of the Petrean database compiled by the authors has confirmed the importance of Australia as a destination in the 21st century, with $21 \%$ of those who left Peterhouse after 2000 moving to Australia (see Figure 4). This has corresponded with the decline in popularity of the United Kingdom, falling from $34 \%$ of $1991-2000$ leavers to $24 \%$ of post-2000 leavers. The proportion moving to South Africa halved from about one quarter of pre-1965 leavers, to just 13\% of 1991-2000 leavers. South Africa may have been less popular as a destination during the 1990s as a result of political upheaval in South Africa when the government repealed its apartheid legislation and the country held its first universal elections, won by the African National Congress. During the post-2000 period of economic and social turmoil in Zimbabwe, however, South Africa regained its position as the top destination (equal with the United Kingdom), while the share of Petreans choosing to remain in Zimbabwe fell below 12\%.

Further analysis was undertaken on 463 African and Asian Petreans in the Petrean database whose ethnicity was identified on the basis of surname. Unlike European Petreans, a majority (55\%) of African and Asian Petreans who left school before 1981 chose to remain in Zimbabwe. However, the proportion has declined steeply over time with just $8 \%$ of post-2000 leavers remaining in Zimbabwe. Australia has become a popular destination, chosen by about one in five of post-2000 leavers consistent with trends found in the census data. About one in five African and Asian Petreans have moved to the USA, which is a much higher proportion than for European Petreans (10\%). 


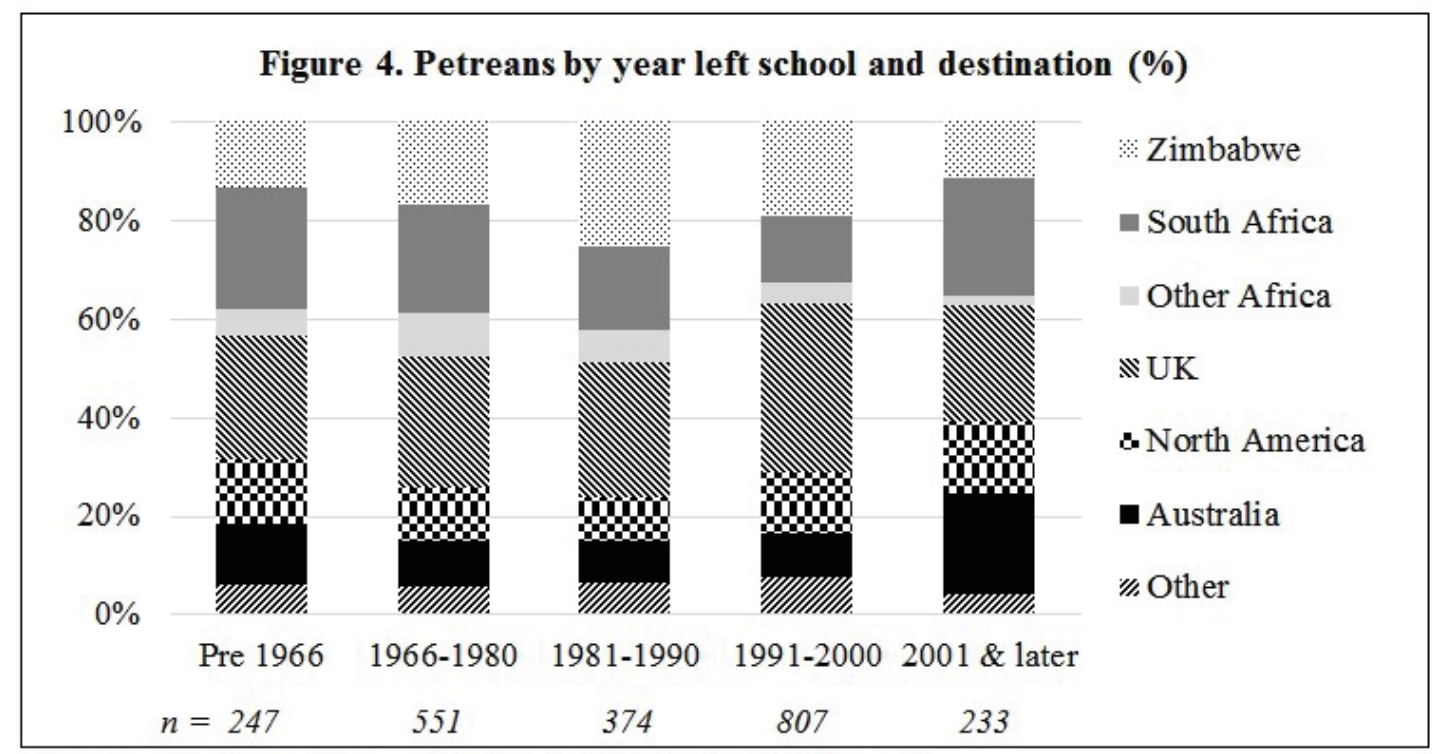

Source: Peterhouse Petrean Society and Petrean Bush Telegraph.

Note: Data compiled from 2212 case histories of school leavers up to 2011.

The migration histories of many Petreans listed on the Peterhouse Petrean Society website indicate that they are a skilled and mobile population. Many have travelled to Australia for tertiary education. Case histories of several Petreans living in Australia show complex migration pathways involving third countries and circular routes. For example, a geologist worked in Zimbabwe, South Africa and Canada before becoming a mining analyst in South Africa. He later moved to Australia and works in mining corporate finance.

\section{The diversity of the Africa-born in Australia}

Africa-born groups in Australia are very heterogeneous, reflecting their diverse origins. Figure 5 shows total settler flows from 1991 to 2013 for four key birthplaces in Africa, disaggregated by migrant type. It shows that settlers from both Zimbabwe and South Africa are predominantly skilled migrants (79\% and 80\%, respectively), whereas those from the Sudan and Horn of Africa are mainly refugees/humanitarian entrants (90\% and 63\%, respectively).

The high proportion of Zimbabweans entering Australia as skilled migrants is in contrast to the situation in the United Kingdom and Canada which were more receptive to humanitarian entrants. Data from the Department of Social Services' Settlement Reporting Facility show that arrivals in Australia of Zimbabwe-born refugees/humanitarian entrants peaked at just 266 in 2008. In contrast, Zimbabwean applications for 
asylum in the United Kingdom peaked at over 7000 in 2002 (Bloch, 2010) and Canada took in over 1300 refugees in 2004 (Crush et al., 2013).

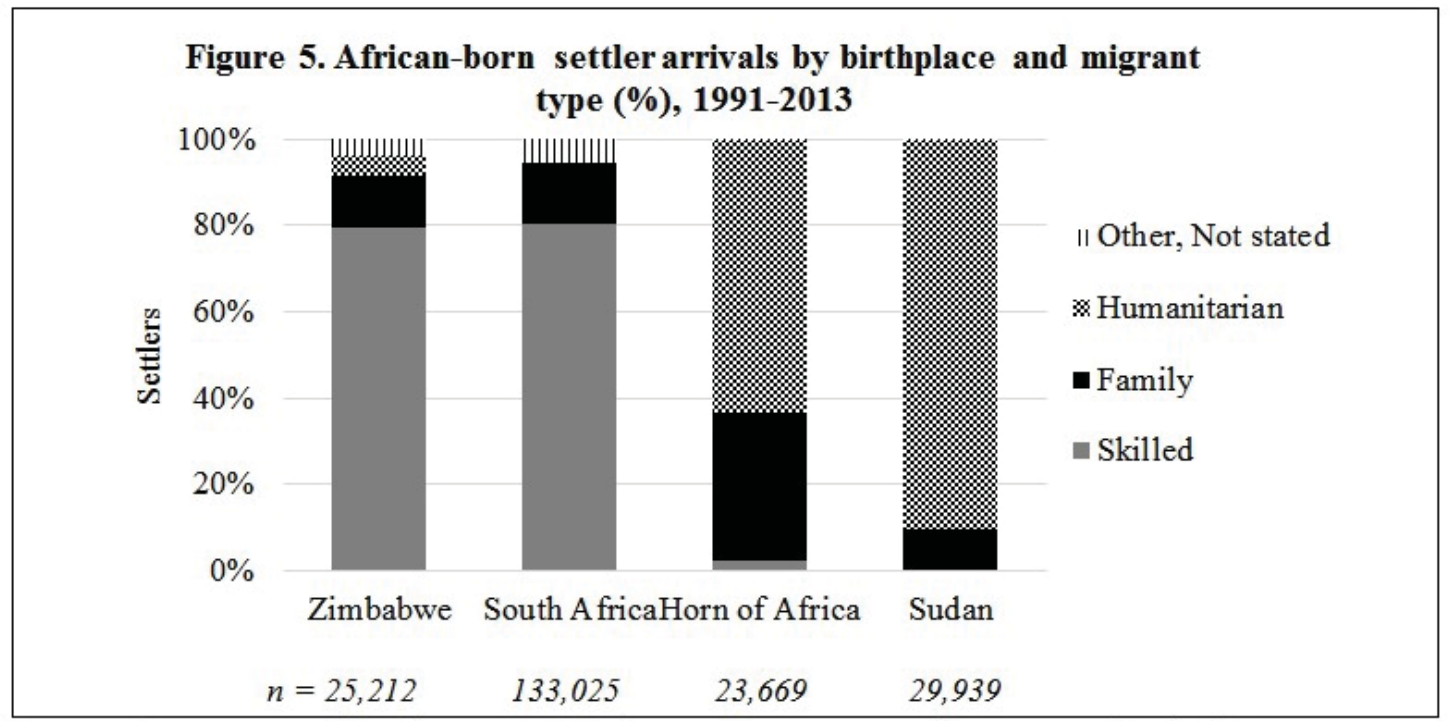

Source: Department of Social Services, Settlement Reporting Facility. Extracted 20/01/2014. Note: Includes persons who arrived as migrants; and temporary entrants who were later granted permanent resident status onshore. Horn of Africa comprises Ethiopia, Eritrea, Djibouti and Somalia.

Australian Government policy had shifted towards skilled migration in the mid-1990s (McDonald, 2015). Nevertheless, it is likely that some Zimbabweans entering Australia as skilled workers were in fact forced migrants or what Kunz (1973) described as "anticipatory refugees", i.e. a person who "arrives in the country of settlement prepared: he knows something of the language, usually has some finance and is informed about the ways in which he can re-enter his trade or profession” (p132).

Employment is a key indicator of successful immigrant settlement in destination countries. Since four in every five Zimbabwe- and South Africa-born settlers have been skilled or business migrants, they should have high rates of employment and low rates of unemployment after migration. Indeed Forrest et al. (2013) found that few South African and Zimbabwean immigrants in a longitudinal survey had any difficulty finding employment six and 18 months after arrival in Australia, consistent with their pre-emigration experience.

Figure 6 shows labour force status in 2011 by sex and birthplace in Africa. Of all groups, Zimbabwe had the largest proportion in employment (86\% of males, $76 \%$ of females aged 15-64), closely followed by South Africa. These two birthplaces also had the smallest proportions who were unemployed and looking for work (3-4\%). Immigrants from the Sudan and Horn of Africa had much higher unemployment (9\%-14\%), as well as a 
large proportion who were not economically active (27\%-59\%). Low levels of participation in the Australian labour force have been linked to low levels of English proficiency among newly-arrived migrants (Richardson et al., 2004). Additionally, men and women born in the Sudan and Horn of Africa are less well-educated on the whole, compared with those from southern Africa (Lucas \& Edgar, 2013).

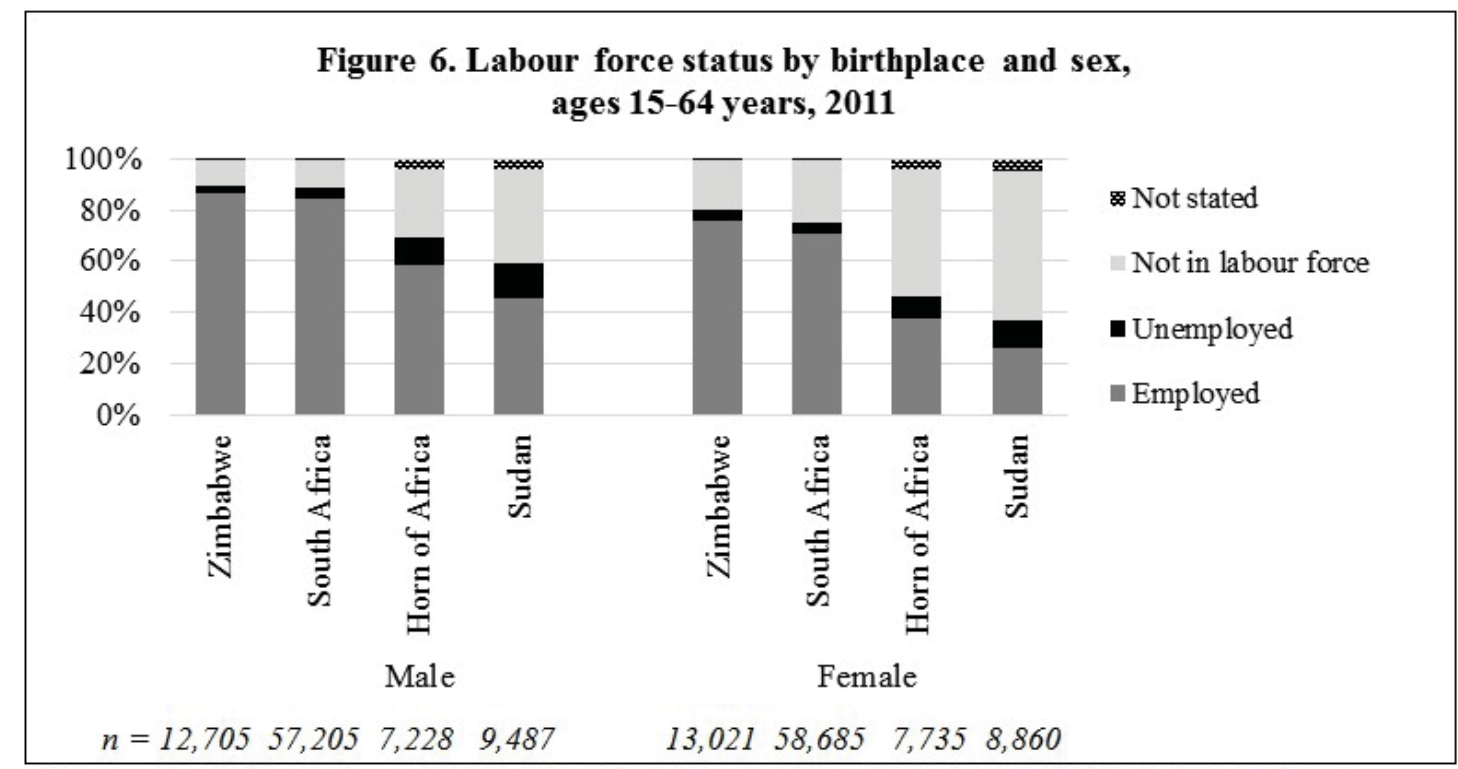

Source: Australian Bureau of Statistics, 2011 Census. Data obtained using TableBuilder software.

Note: Horn of Africa comprises Ethiopia, Eritrea, Djibouti and Somalia. Sudan includes South Sudan.

\section{European and African ancestry and language groups}

There have been striking changes in the composition of Zimbabwean immigrants to Australia over time. Although 20th century flows from Zimbabwe to Australia were predominantly European, in the early 21st century as the Zimbabwean economy went into free fall there was an exodus of African Zimbabweans. A 2001 survey of working professionals in Zimbabwe, conducted "just as the outflow of skilled migrants began to intensify” (Tevera \& Crush, 2010, p. 121), found that $67 \%$ were likely or very likely to emigrate within five years and the most popular destinations in order of preference were the USA, the United Kingdom, Botswana, South Africa, Australia/New Zealand, and Canada (Tevera \& Crush, 2010). The survey sample comprised 738 professionals, $94 \%$ of whom were of African descent.

Data from the 2011 census show that in the early 21st century, the share of European Zimbabweans (mainly of British or Irish ancestry) has diminished while the share of African Zimbabweans has become dominant. Figure 7 shows the Zimbabwe-born population in 2011 by ancestry and 
year of arrival in Australia. Two-thirds of those who arrived before 1980 were of British or Irish descent, providing a reminder that immigrants to the former Rhodesia were largely from the United Kingdom. A further $11 \%$ of pre-1980 settlers identified with other European ancestries; 6\% were enumerated as 'Zimbabwean' ancestry but, since Zimbabwe did not exist as a country before 1980, these were most likely Europeans who wrote 'Rhodesian' in response to the ancestry question and had their response recoded to 'Zimbabwean'.

In contrast, of the cohort who arrived in 2007-11, just $25 \%$ of Zimbabwe-born identified as British, Irish or other European ancestry. There has been a corresponding jump in the proportion who describe their ancestry as Zimbabwean (40\% of 2007-2011 arrivals) or African (24\%, including “other African” ancestries).

Observed changes in language distribution similarly indicate increasing numbers of African Zimbabweans in Australia. The Australian census records the language spoken at home rather than first or native language. Shona and Ndebele are the major Indigenous languages in Zimbabwe and many African Zimbabweans speak one of these languages at home (mostly Shona) whereas most European Zimbabweans speak English at home. The 2001 census enumerated just 404 Shona speakers (Ndebele speakers were not identified). Between 2006 and 2011, Shona speakers increased by 186\% (from 2,796 to 8,006) and Ndebele speakers increased by 170\% (from 394 to 1,064) (DIBP 2014). Although language data obtained from the Department of Social Services' Settlement Reporting Facility are incomplete, they show that the number of settler arrivals to Australia whose main language was Shona was tiny (5 persons) in 2001 but increased every year until 2008 when it reached 146 persons; settlers whose main language was Ndebele increased from zero in 2001 to 17 in 2007, falling slightly to 15 in 2008.

Figure 8 shows graphically the change in languages spoken by the Zimbabwe-born population in Australia in the intercensal period 20062011. The number of Zimbabwe-born Shona speakers increased from 2,659 in 2006 to 7,242 in the 2011 census. Further analysis of the 2011 census finds that 53\% of Zimbabwe-born who arrived in the period 2007-2011 spoke an African language, primarily Shona.

Figure 9 shows the age/sex profiles in 2006 and 2011 for Zimbabweborn who speak an African language compared with those who speak English at home. The figure on the left shows the substantial growth in the African language population between 2006 and 2011. African language speakers are notably younger, mostly below 40 years of age, compared with 
the larger population of English speakers who are predominantly aged between 35 and 60 reflecting their earlier arrival in Australia. African language speakers are more likely to be female (52\%) than male, whereas English language speakers have a balanced sex ratio.

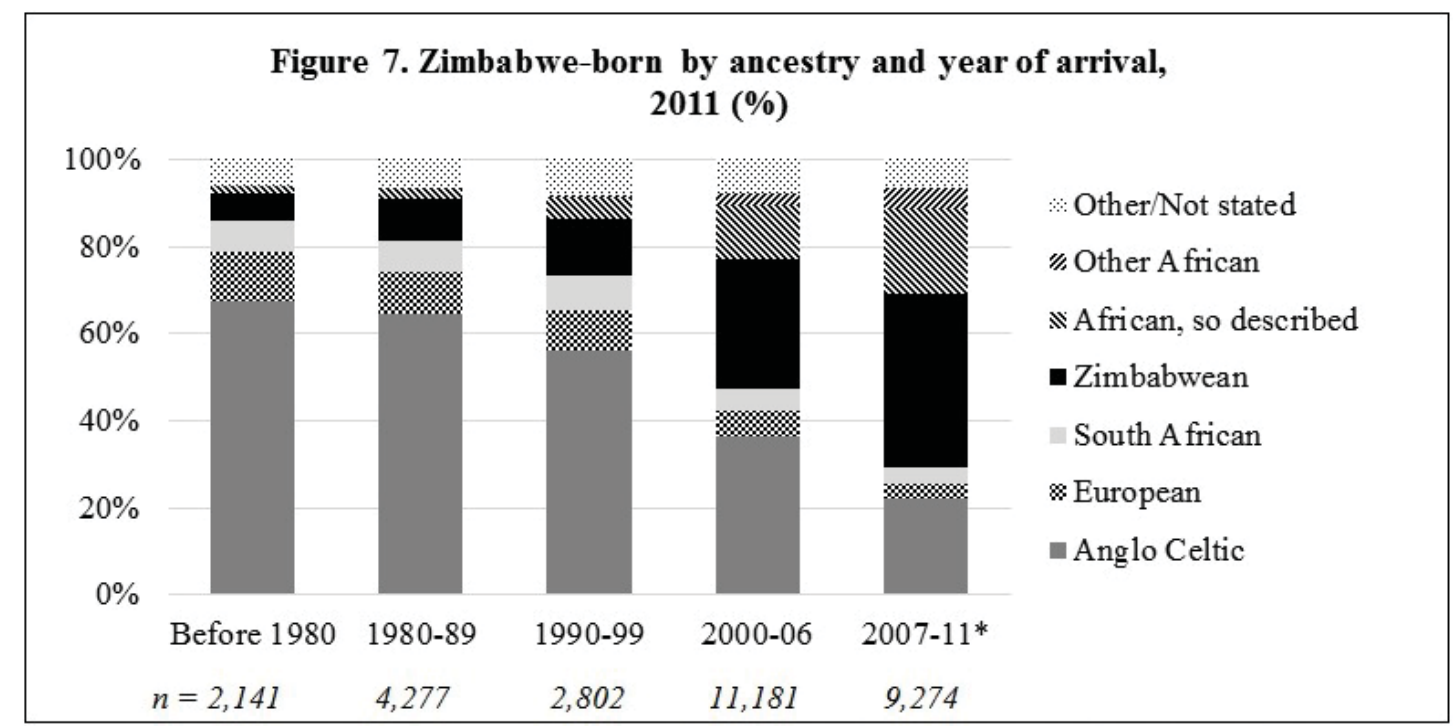

Source: Australian Bureau of Statistics, 2011 Census. Data obtained using TableBuilder software. Note: Anglo-Celtic includes British, English, Scottish, Welsh and Irish. South African includes South African and Afrikaner. ${ }^{*} 2007-11$ arrival period is to 9 August 2011.

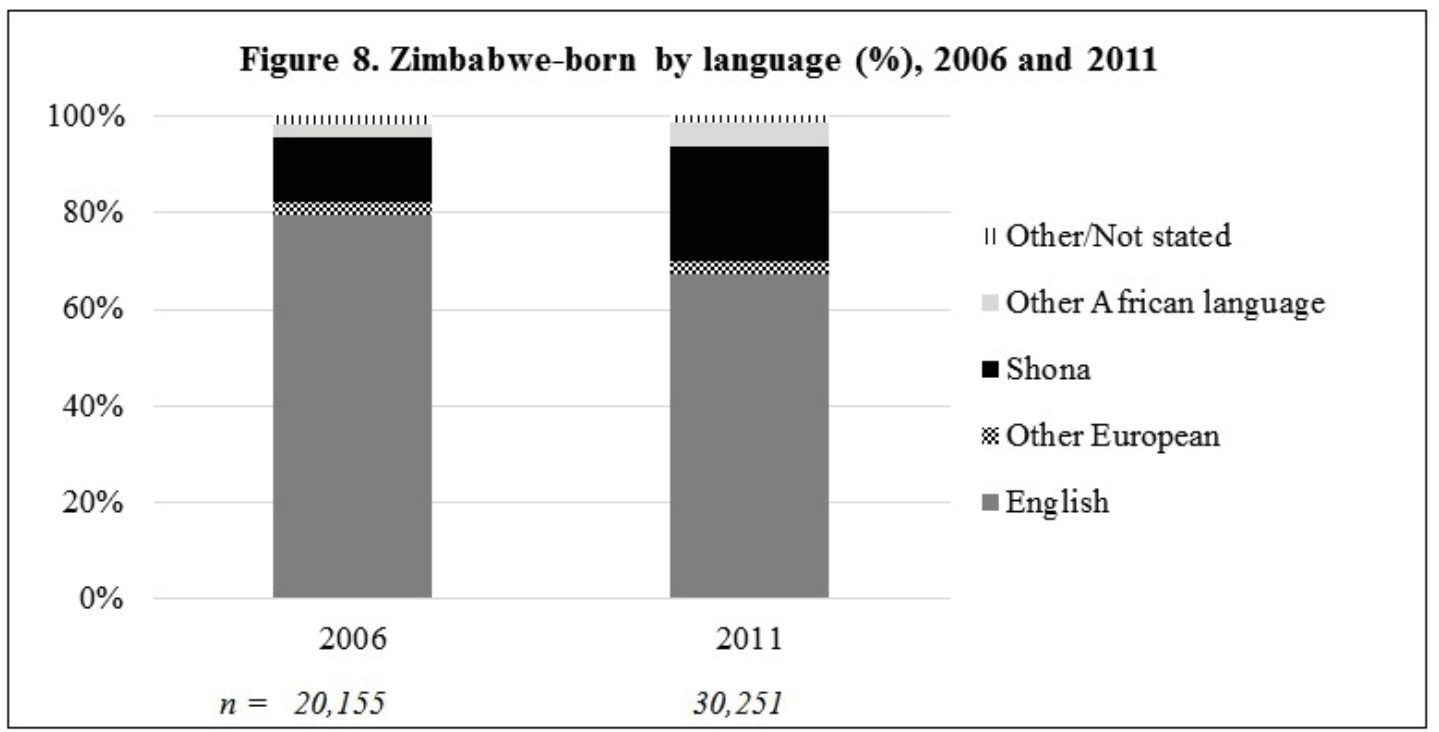

Source: Australian Bureau of Statistics, 2006 and 2011 Censuses. Data obtained using TableBuilder. Note: Data are for language spoken at home. 


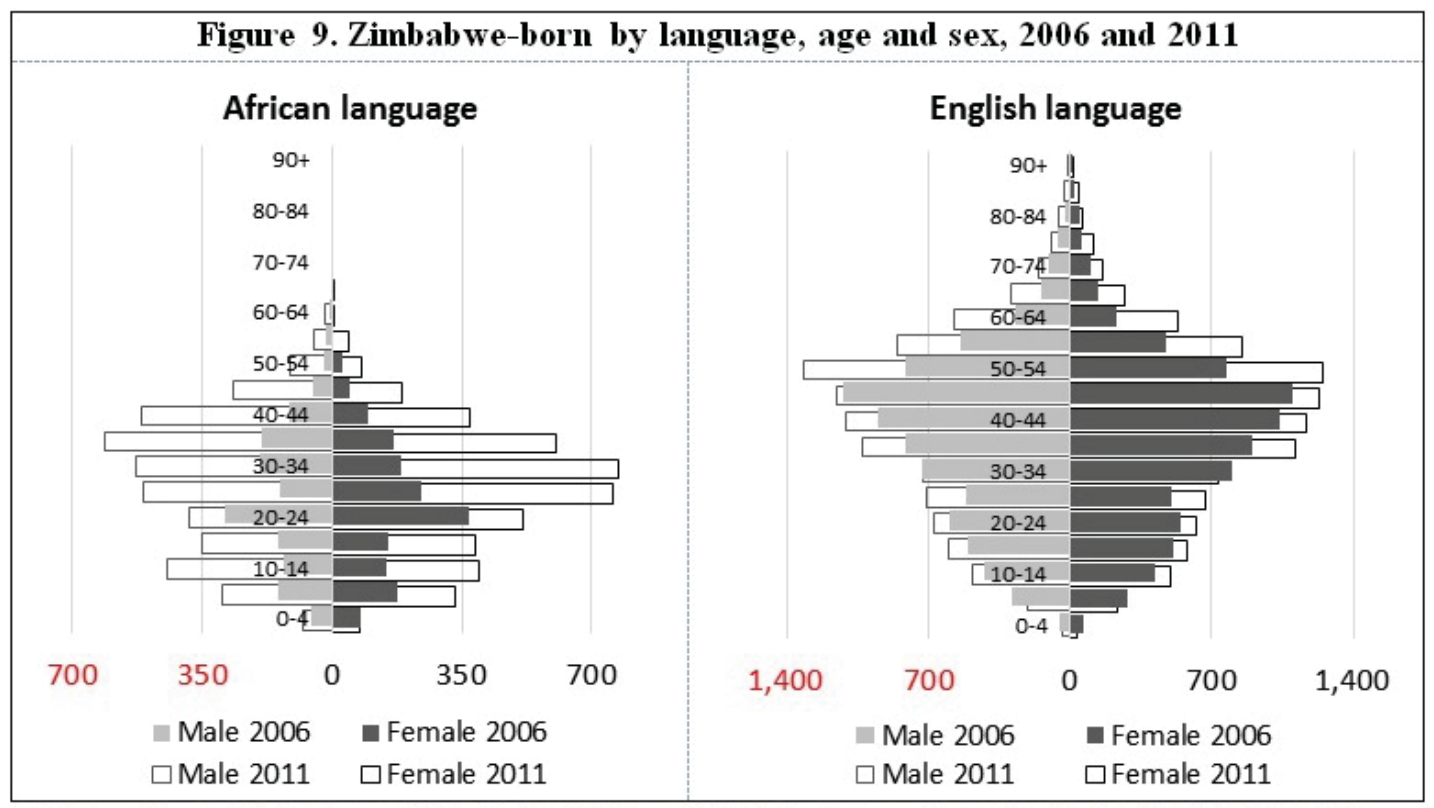

Source: Australian Bureau of Statistics, 2006 and 2011 Censuses. Data obtained using TableBuilder.

At the 2011 census, 75\% of the Zimbabwe-born aged 15 years and over had some form of higher non-school qualification compared to $56 \%$ of the Australian population (Department of Social Services, 2014). Further analysis of those aged 20 to 59 finds that around $15 \%$ of both males and females who spoke an African language had no qualifications, whereas for English speakers, the corresponding percentages were higher: $18 \%$ of males and $24 \%$ of females.

The occupational profiles of male and female African language speakers compared with English speakers, and the Australian population as a whole, are presented in Figure 10. Both English and African language speakers are strongly represented in professional/managerial occupations compared with the total Australian population, which suggests that skilled Zimbabweans have good prospects in Australia regardless of ethnicity.

We find notable occupational differences by sex and language: Englishspeaking males are the most likely to be managers (22\%), while a majority of females who speak an African language at home (52\%) have professional occupations. Approximately 22-23\% of males from both language groups are technicians and trades workers, as are males Australiawide. Females are more likely to be community and personal service workers (28\% of African language speakers) or clerical and administrative workers (30\% of English speakers). While 24\% of women in the Australian population are clerical and administrative workers, very few (5.4\%) African language speakers work in these occupations. 


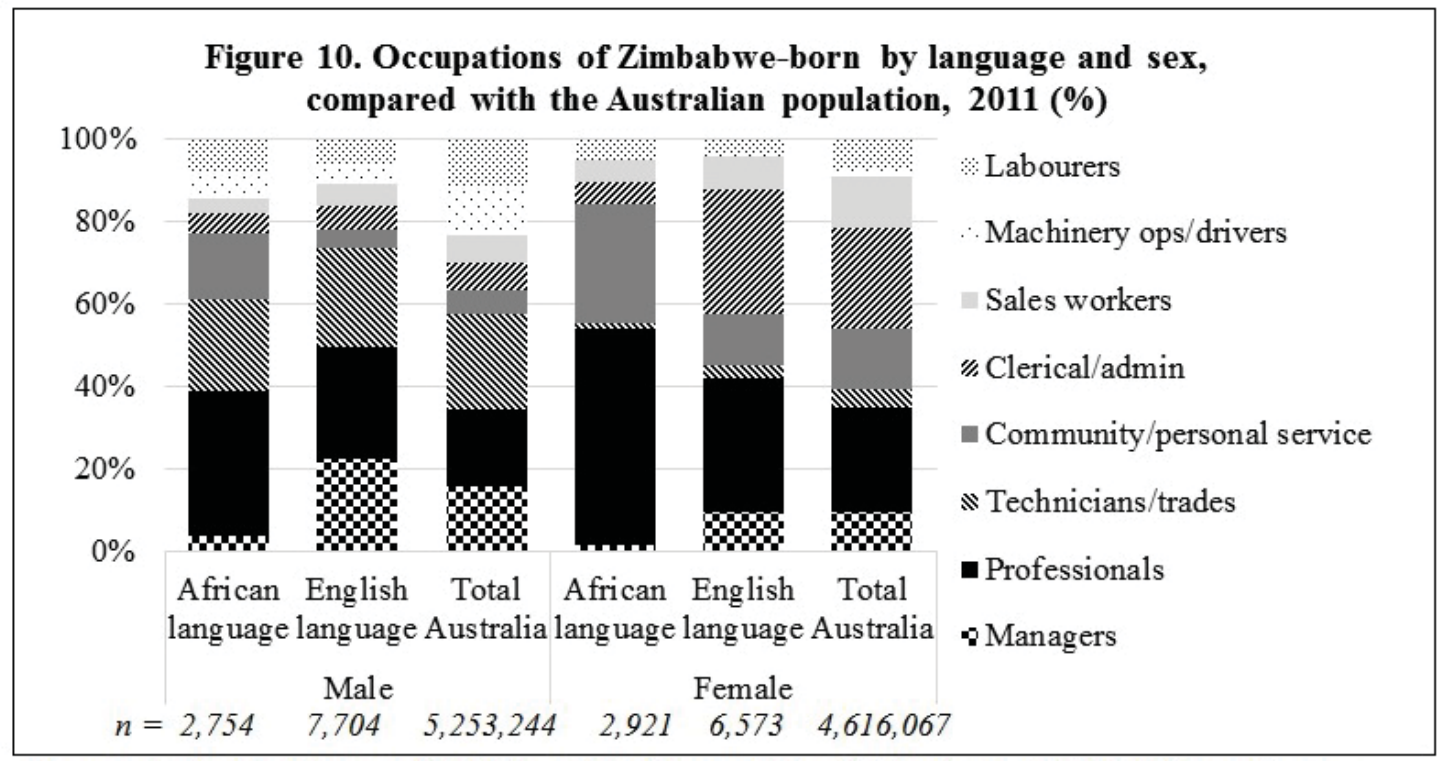

Source: Australian Bureau of Statistics, 2011 Census. Data obtained using TableBuilder software. Note: Language data are for language spoken at home. Excludes not stated occupation.

As in Australia, Zimbabwean immigrants in the United Kingdom are mainly highly-educated professionals from middle and upper class families in Zimbabwe (Pasura, 2010; McGregor, 2007). Nevertheless, McGregor (2007) found evidence that many in the United Kingdom were experiencing deskilling and a loss of status by working in the personal care sector "with little prospect of using their qualifications” (p. 802). This does not appear to be the case in Australia since very few Zimbabwe-born work in this sector. Further analysis of 2011 census data finds that only 8.7\% of Zimbabweborn females and 3.2\% of males were working as aged, disabled, nursing support or personal care workers.

Figure 11 shows the industries in which the Zimbabwe-born work by sex and language, compared with the industries employing all Australian males and females. What stands out is that almost $70 \%$ of females who speak an African language work in the health care and social assistance industry. Many male African language speakers (29\%) and female English speakers (22\%) also work in this sector. Among males, $7.6 \%$ of African language speakers and 6.6\% of English speakers work in the mining industry, greatly exceeding the share in the Australian population $(2.7 \%$ of males). These figures reflect the situation during the peak of the recent mining boom in Australia (Tulip, 2014).

Among Zimbabwe-born with permanent resident status who arrived between 2000 and 2005, 91\% of English-speakers and 73\% of African language speakers had taken up Australian citizenship (source: 2011 Australian Census and Migrants Integrated Dataset). Since dual citizenship 
is not allowed for Zimbabwean citizens, the substantial number taking up Australian citizenship are unlikely to resettle in Zimbabwe.

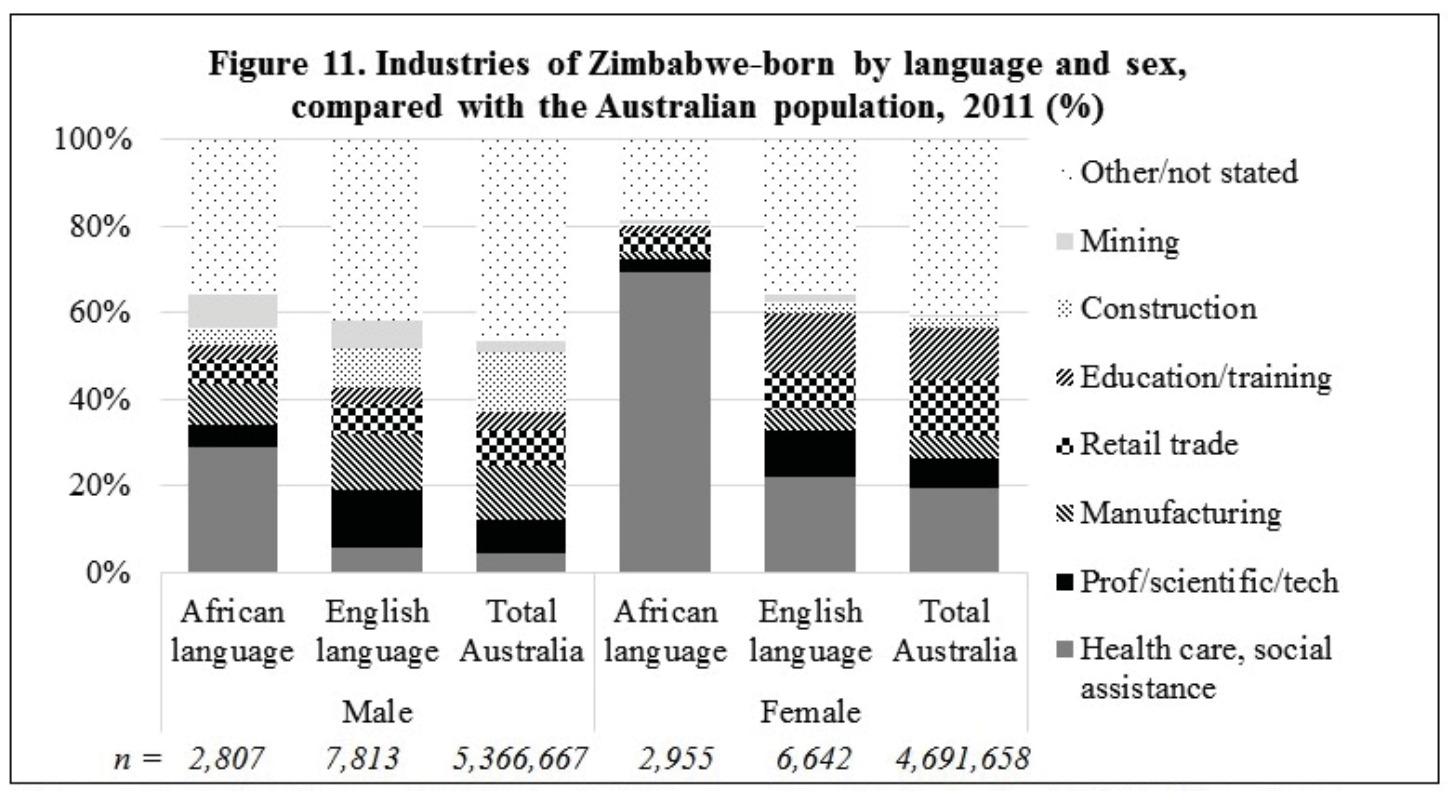

Source: Australian Bureau of Statistics, 2011 Census. Data obtained using TableBuilder software.

Note: Employed persons only. Language data are for language spoken at home.

\section{Conclusion}

The historical analysis above shows how the large flows from Zimbabwe to Australia since 2000 have reflected government policies and the state of the economy in each country as well as more restrictive United Kingdom policies. Australian data for the 2006-2011 intercensal period show sustained growth of the Zimbabwe-born population, with African language speakers comprising the majority of those who arrived in the most recent period from 2007 to 2011.

The Zimbabwe-born in Australia, like the South Africa-born, are a highly skilled, educated and advantaged group compared with other groups from Africa, especially those of primarily refugee origin from the Sudan and Horn of Africa. Zimbabweans do well in the Australian labour market and this situation should persist given that newcomers will continue to enter under skilled migration pathways which reflect government policy settings. However, the peak of the recent mining boom in Australia has passed and the forthcoming 2016 census should show a change in occupational structures as other sectors play a greater role in the Australian economy. Additionally, the 2016 census will provide an opportunity to examine a wider range of emerging African source countries providing skilled migrants. 
When the 2016 Australian census data are released, the number of Zimbabwe-born is expected to show a further increase, although the rate of growth may have eased. A factor inhibiting new arrivals is that Australia's economic outlook has become less favourable than at the peak of the mining boom, and the demand for skilled workers is relatively subdued across most industries (Department of Employment, 2015). The small population of Europeans remaining in Zimbabwe no longer provides a significant source of Australian immigrants, so Africans will form the majority of new arrivals. Zimbabwean immigrants may continue to arrive via other major destinations, notably South Africa.

Persons identifying as Rhodesian have been re-coded as Zimbabwean ancestry and this is likely to be repeated in the 2016 census. Younger whites born and raised in Zimbabwe may identify as Zimbabwean (for example, see Fisher, 2010). The census question on language spoken at home will measure language maintenance for Shona and Ndebele speakers.

Further research is needed on the longer-term settlement outcomes of both European and especially African components of Zimbabwe-born in Australia, as well as on the growing second generation born in Australia. Unfortunately the Australian census has not recorded parental country of birth since 1996, so identification of second generation Zimbabweans in the census has so far been problematic. The 2016 census will record mother's/father's country of birth and this richer dataset will provide a greater opportunity to analyse second generation Zimbabwean (and other African) groups.

A detailed analysis of the migration histories of Petreans, although highly selective, could indicate the extent to which Zimbabwean migrants come to Australia directly or via other countries; whether studying in Australia is a common pathway to permanent residence; and whether Australia is a final destination or a stepping stone to resettlement in other countries.

Since citizenship is an indicator of continued settlement, it will be important to monitor trends in the take-up of Australian citizenship when 2016 census data are available. Return migration to Zimbabwe is not expected to be significant given the country's poor economic outlook, with industrial underproduction, lack of competitiveness and an unsustainable external debt (African Development Bank, 2014). 


\section{Bibliography}

ABC, Australian Broadcasting Corporation. (2003). The life of Andrew Murray: Former freedom fighter now Democrats Senator. Broadcast: 24 October 2003, Tom Baddeley reporter. http://www.abc.net.au/ stateline/wa/content/2003/s976000.htm.

African Development Bank. (2014). Zimbabwe Economic Outlook 2014. http://www.afdb.org/en/countries/southern-africa/zimbab we/zimbabwe-economic-outlook/.

Australian Institute of Company Directors. (2014). Q and A with Launa Inman. Company Director Magazine, 1 Sep 2014. www.company directors.com.au/Director-Resource-Centre/Publications/CompanyDirector-magazine/2014-back-editions/September/Interview-Q-andA-with-Launa-Inman.

Bloch, A. (2010). Transnational lives: The experience of Zimbabweans in Britain. In J. Crush \& D. Tevera (Eds.), Zimbabwe's Exodus (pp.156-176). Cape Town: Southern Africa Migration Programme.

Bratton, M., \& Masunungure, E. (2006). Popular reaction to State repression: Operation Murambatsvina in Zimbabwe. African Affairs, 106 (422):21-45.

Brownell, J. (2008). The hole in Rhodesia's bucket: White emigration and the end of settler rule. Jnl of Sthrn African Studies, 34(3): 591-610.

Bundu Times. The Newsletter of the Rhodesian Association of Western Australia. http://rhodesianassociation.com/bundu-times/.

Crush, J., \& Tevera, D. (2010). Exiting Zimbabwe. In J. Crush \& D. Tevera (Eds.), Zimbabwe's Exodus (pp. 1-49). Cape Town: Southern Africa Migration Programme.

Crush, J., Chikanda, A., Pendleton, W., Caesar, M., Ramachandran, S., Eberhardt, C., \& Hill, A. (2013). Divided Diasporas: Southern Africans in Canada. Special report by the Centre for International Governance Innovation and the Southern African Migration Programme.

Department of Employment. (2015). The skilled labour market: a pictorial overview of trends and shortages 2015. https://docs.employment. gov.au/collections/national-overview-reports.

Department of Immigration and Border Protection (2014). The People of Australia: Statistics from the 2011 Census. www.border.gov.au/ ReportsandPublications/Documents/research/people-australia-2013statistics.pdf.

Department of Social Services. (2014). Community Information Summary: Zimbabwe-born.www.dss.gov.au/our-responsibilities/settlement- 
and-multicultural-affairs/programs-policy/a-multiculturalaustralia/programs-and-publications/community-informationsummaries.

Dutton, C. (2015). David's destiny ... support gets star to the big game. The Canberra Times, 31 October 2015, 4.

Fisher, D. (2007). Into Africa. In M. Dee \& F. Volk (Eds.), Women with a Mission (pp. 157-177). Canberra: DFAT.

Fisher, J. L. (2010). Pioneers, Settlers, Aliens, Exiles: the decolonisation of white identity in Zimbabwe. Canberra: ANU E Press.

Forrest, J., \& Johnston, R. (1999). Disadvantage, discrimination and the occupational differentiation of migrant groups in Australia. International Journal of Population Geography, 5, 277-296.

Forrest, J., Poulsen, M., \& Johnston, R. (2006). A "multicultural model" of the spatial assimilation of ethnic minority groups in Australia's major immigrant-receiving cities. Urban Geography, 27, 441-463.

Forrest, J., Johnston, R., \& Poulsen, M. (2013). Middle-class diaspora: recent immigration to Australia from South Africa and Zimbabwe. South African Geographical Journal, 95(1), 50-69.

Geenty, M. (2009). No more guns under bed for Wallabies prodigy. 12 July 2009.http://www.voxy.co.nz/sport/no-more-guns-under-bedwallabies-prodigy/5/18142.

Godwin, P., \& Hancock, I. (1993). Rhodesians Never Die. Oxford: Oxford University Press.

Gordon-Brown, A. (1959). The Year Book and Guide to Southern Africa. London: Robert Hale.

Hammer, J. (2010). (Almost) Out of Africa: the white tribes. World Affairs, May/June 2010. http://www.worldaffairsjournal.org/article/almostout-africa-white-tribes.

Hugo, G. (1999). Atlas of the Australian People. Canberra: Commonwealth of Australia, 214-15.

Hugo, G. (2009). Migration between Africa and Australia: a demographic perspective. Sydney: Australian Human Rights Commission. http://www.hreoc.gov.au/africanaus/papers/africanaus_paper_hugo.h tml\#Heading599.

Kay, G. (1988). Zimbabwe. In Africa South of the Sahara (pp. 1136-1163). London: Europa Publications.

Kennedy, B. (1988). Southern Africans. In The Australian People. Sydney: Angus \& Robertson, 801-02.

Kunz, E. F. (1973). The refugee in flight: Kinetic models and forms of displacement. The International Migration Review, 7 (2), 125-146. 
Lucas, D., \& Edgar, B. (2013). Africans in Australia 2011: Their demography and human capital. Paper presented to the Annual Conference of the African Studies Association of Australasia and the Pacific, Perth. http://afsaap.org.au/conference/conference-2013/.

Lucas, D., \& Edgar, B. (2015). Zimbabwe's exodus to Australia. SAMP Migration Policy Brief No. 30. http://www.queensu.ca/samp/ sampresources/samppublications.

Lucas, D., Jamali, M., \& Edgar, B. (2011). Zimbabwe's exodus to Australia. Paper presented to the Annual Conference of the African Studies Association of Australasia and the Pacific, held at Flinders University. http://afsaap.org.au/assets/Lucas_Jamali_Edgar.pdf.

McDonald, P. (2015). International Migration and Employment in Australia. Population Review, 54 (2), 1-12.

McGregor, J. (2007). Joining the BBC (British Bottom Cleaners): Zimbabwean migrants and the UK care industry. Journal of Ethnic and Migration Studies, 33(5), 801-824.

Mlambo, A. (2010). A history of Zimbabwean migration to 1990. In J. Crush \& D. Tevera (Eds.), Zimbabwe's Exodus (pp. 52-76). Cape Town: Southern Africa Migration Program.

National Museum Australia (2014). Audio on demand transcript. Landmark women: Julia Newton-Howes. http://www.nma.gov.au/audio/ transcripts/NMA_LMW_Newton_Howes_20140627.html

Nugent, P. (2004). Africa since Independence. Basingstoke: Palgrave Macmillan.

Pasura, D. (2010). Regendering the Zimbabwean diaspora in Britain. In J. Crush \& D. Tevera (Eds.), Zimbabwe’s Exodus (pp. 207-222). Cape Town: Southern Africa Migration Program.

Peterhouse Petrean Society. http://www.petreans.co.zw/petrean-news.

Petrean Bush Telegraph. http://home.vicnet.net.au/ petrean/ petbush.htm.

Pillinger J. (2012) Australia National Report: Quality Healthcare and Workers on the Move. Paris: Public Services Int. www.world-psi.org/ sites/default/files/documents/research/psi_australia_report.pdf.

Richardson, S., Robertson, F., and Ilsley, D. (2001). The Labour Force Experience of New Migrants. Canberra: The National Institute of Labour Studies, Flinders University.

Richardson, S., Stack, S., Lester, L., Healy, J., Ilsley, D., and Horrocks, J. (2004). The Changing Settlement Experience of New Migrants. Canberra: National Institute of Labour Studies, Flinders University. 
Settlement Services International. (2014). My Story - Oliver Zvinaiye Maboreke. 18 March 2014. http://www.ssi.org.au/news/ssi-newsblog/188-my-story-oliver-zvinaiye-maboreke.

Tevera, D., \& Crush, J. (2010). Discontent and Departure: Attitudes of Skilled Zimbabweans Towards Emigration. In J. Crush \& D. Tevera (Eds.), Zimbabwe's Exodus (pp. 112-132). Cape Town: Southern Africa Migration Program.

Tevera, D., \& Zinyama, L. (2002). Zimbabweans Who Move: Perspectives on International Migration in Zimbabwe. SAMP Migration Policy Series No. 25. Idasa: Cape Town.

Tulip, P. (2014). The effect of the mining boom on the Australian economy. Reserve Bank of Australia Bulletin, 2014(4), 17-22. http://www.rba.gov.au/publications/bulletin/2014/dec/index.html.

United Nations Population Division. (2015). International Migration Flows to and from Selected Countries: The 2015 Revision. http://www.un.org/en/development/desa/population/migration/data/e mpirical2/migrationflows.shtml .

United Kingdom. Office for National Statistics. (2013). 2011 Census Analysis: Immigration patterns of non-UK born populations in England and Wales in 2011. https://www.ons.gov.uk/people populationandcommunity/populationandmigration/internationalmigr ation\#publications.

Western Sydney University, n.d. Challenging Racism Project: National Level Findings. http://www.westernsydney.edu.au/ssap/ssap/ research/challenging_racism.

Wooden, M. (1994). The Labour-market Experience of Immigrants. In M. Wooden, R. Holton, G. Hugo \& J. Sloan (Eds.), Australian Immigration: A Survey of the Issues (pp 218-279). Canberra: Bureau of Immigration Research.

Zimbabwe. Central Statistical Office (1985). Main Demographic Features of the Population of Zimbabwe. Harare.

Zimbabwe. Central Statistical Office (1998). Inter-Censal Demographic Survey Report. Harare.

Zimbabwe. Central Statistical Office (2004). 2002 Zimstat. Harare.

Zimbabwe. Population Census Office (2014). Census 2012 National Report. Harare: Zimbabwe National Statistics Agency.

Zinyama, Lovemore. (1990). International migrations to and from Zimbabwe and the influence of political changes on population movements 1965-1987. International Migration Review, 24(4), 748767. 